\title{
PENGARUH PEMBERIAN JUS MENTIMUN (Cucumis sativus $l$ ) TERHADAP PENURUNAN TEKANAN DARAH PADA PENDERITA HIPERTENSI WANITA USIA 40-60 TAHUN
}

\author{
Aisyah, Enny Probosari* \\ Program Studi Ilmu Gizi Fakultas Kedokteran Universitas Diponegoro \\ Jl.Dr.Sutomo No.18, Semarang, Telp (024) 8453708, Email : gizifk@undip.ac.id
}

\begin{abstract}
Background: Hypertension is a health problem that need to be cured because of their high prevalence and the effect may happen. Incident of hypertension increased at 40-60 years old and occured more frequently in women. Cucumber (Cucumis sativus l) consist of kalium, calsium, and magnesium which work in contrast with natrium that have hipotensive effect.

Objective : This study aims to determine the effect of cucumber (Cucumis sativus l) juice consumption to decrease blood pressure in women 40-60 years old with hypertension.

Metode : Pre and Post Test Control Groups Design was conducted for twice in 7 days in 30 women 40-60 years old hypertensive live in Jomblang Semarang taken using quota sampling method. Blood pressure was measured using a sphygmomanometer. Natrium, kalium, calcium and magnesium intake was assessed by food recall method. BMI was obtained from the measurement weight compared with height measured using digital scales and microtoise. Statistical analyses were performed with Paired t test and Wilcoxon.

Result : There was a significant decreased in systolic blood pressure $(p=0,000)$, and diastolic blood pressure $(p=0.035)$ in treatment group. After cucumber juice consumption, the systolic blood pressure of treatment group was decreased 16,00 \pm 8,062 SD mmHg and diastolic was decreased 6,67 \pm 6,726 SD mmHg.

Conclusion : Consumption of cucumber juice decrease in systolic blood pressure and diastolic blood pressure in hypertension.

Keywords: blood pressure; cucumber juice; hypertension
\end{abstract}

\begin{abstract}
ABSTRAK
Latar Belakang : Hipertensi merupakan masalah kesehatan yang perlu diperhatikan karena angka prevalensinya yang tinggi dan akibat jangka panjang yang ditimbulkannya. Kejadian hipertensi meningkat pada usia 40-60 tahun dan lebih banyak terjadi pada wanita. Mentimun (Cucumis sativus l) mengandung kalium, kalsium, dan magnesium yang bekerja berkebalikan dengan natrium yang mempunyai efek terhadap penurunan tekanan darah.

Tujuan : Penelitian ini bertujuan untuk membuktikan pengaruh jus mentimun (Cucumis sativus l) terhadap penurunan tekanan darah pada penderita hipertensi wanita usia 40-60 tahun.

Metode : Penelitian ini menggunakan 30 subjek dengan metode Pre and Post Test Control Groups Design dengan subjek wanita yang berusia 40-60 tahun yang tinggal di pemukiman Kelurahan Jomblang Semarang dan menderita hipertensi. Pengambilan subjek menggunakan metode kuota sampling. Tekanan darah sistolik dan diastolik diukur menggunakan sphygmomanometer. Data asupan natrium, kalium, kalsium dan magnesium diperoleh melalui kuesioner food recall. Data IMT diperoleh dari pengkuran berat badan dibandingkan dengan tinggi badan yang diukur menggunakan timbangan digital dan microtoise. Data dianalisis menggunakan uji Paired t test pada data yang berdistribusi normal dan uji Wilcoxon pada data yang berdistribusi tidak normal

Hasil : terdapat penurunan yang bermakna pada tekanan darah sistolik $(p=0,000)$ dan tekanan darah diastolik ( $p$ $=0,002$ ) kelompok perlakuan. Setelah konsumsi jus mentimun, tekanan darah sistolik kelompok perlakuan mengalami penurunan 16,00 \pm 8,062 SD mmHg dan diastolik menurun 6,67 \pm 6,726 SD mmHg.
\end{abstract}

Simpulan : Pemberian jus mentimun mampu menurunkan tekanan darah sitolik dan diastolik pada penderita hipertensi.

Kata kunci: tekanan darah; jus mentimun; hipertensi

\section{PENDAHULUAN}

Hipertensi merupakan masalah kesehatan yang perlu diperhatikan karena angka prevalensinya yang tinggi dan akibat jangka panjang yang ditimbulkannya. ${ }^{1} \quad$ Seseorang dikatakan hipertensi apabila tekanan darah sistolik $\geq 140 \mathrm{mmHg}$ dan atau tekanan darah diastolik $\geq 90$ $\mathrm{mmHg}$, atau bila pasien memakai obat antihipertensi. ${ }^{2}$ Menurut penelitian yang dilakukan di Indonesia, menunjukkan sebanyak $25,8 \%$ penduduk berusia di atas 18 tahun adalah penderita hipertensi, dan dari klasifikasi propinsi diketahui sebanyak $26,4 \%$ penduduk Jawa Tengah menderita hipertensi. ${ }^{3}$ Angka kejadian hipertensi di Semarang dalam kurun waktu 5 tahun terakhir mencapai lebih dari $40 \% .^{4}$

Faktor yang mempengaruhi hipertensi antara lain ras, umur, jenis kelamin, obesitas, 
kurangnya aktivitas, kurangnya asupan kalium, kalsium, magnesium dan serat, asupan tinggi lemak, tinggi natrium, konsumsi alcohol berlebih, kebiasaan merokok, dan adanya riwayat hipertensi dalam keluarga. ${ }^{1,2,5}$ Berdasarkan penelitian diketahui bahwa diet yang menitik beratkan pada makanan rendah lemak, tinggi sayur dan buahbuahan mampu menurunkan tekanan darah sistolik sebesar $11,4 \mathrm{mmHg}$ dan diastolik sebesar 5,5 $\mathrm{mmHg}$ pada penderita hipertensi. ${ }^{6}$ Hasil penelitian lain menunjukkan bahwa dengan pemberian buah yang banyak mengandung kalium, kalsium, dan magnesium seperti papaya, semangka, melon, dan belimbing demak dapat menurunkan tekanan darah secara signifikan. ${ }^{7,8}$

Menurut hasil penelitian, pemberian jus mentimun sebanyak 100 gram selama 6 hari dengan melihat perbedaan penurunan tekanan darah pada 2 jam, 6 jam, dan 9 jam setelah perlakuan dapat menurunkan tekanan darah secara bermakna dan penurunan terbesar terjadi pada 2 jam setelah perlakuan pada hari 4 dan $5 .{ }^{9}$ Penelitian serupa dilakukan selama tujuh hari dengan melihat tekanan arteri rata-rata (MAP) pada kelompok kontrol dan perlakuan, dan didapatkan penurunan MAP sebesar $13,8 \mathrm{mmHg} .{ }^{10}$ Penelitian lain dilakukan selama tiga hari dan diketahui terdapat penurunan tekanan darah sistolik sebanyak $9 \mathrm{mmHg}$ dan tekanan darah diastolik sebanyak $4 \mathrm{mmHg}$ secara bermakna. ${ }^{11}$ Penelitian lain yang diakukan di Dusun I Desa Pulau Sejuk Kecamatan 50 Kabupaten Batu Bara mengenai pemberian mentimun didapatkan hasil $40 \%$ responden mengalami penurunan tekanan darah ke klasifikasi normal tinggi (pre hipertensi), $50 \%$ mengalami penurunan menjadi normal, dan $10 \%$ tidak mengalami penurunan. ${ }^{12}$ Pada penelitian ini rentang umur responden terlalu jauh dan jenis kelamin responden tidak dibedakan. Sedangkan dari referensi diketahui kejadian hipertensi meningkat pada usia 40-60 tahun dan pada wanita memiliki prevalensi lebih tinggi. ${ }^{13}$

Berdasarkan hal-hal tersebut, maka penelitian ini dilakukan untuk membuktikan pengaruh pemberian jus mentimun (Cucumis sativus $l$ ) terhadap penurunan tekanan darah pada penderita hipertensi wanita usia 40-60 tahun. Hasil dari penelitian ini diharapkan dapat memberikan informasi mengenai pengaruh pemberian jus mentimun (Cucumis sativus $l$ ) terhadap penurunan tekanan darah pada penderita hipertensi wanita usia 40-60 tahun dan dapat dijadikan bahan masukan bagi penelitian berikutnya.

\section{METODE}

Penelitian ini dilaksanakan di pemukiman warga kelurahan Jomblang Semarang pada bulan Juni-Agustus 2014 dengan disiplin ilmu yang terkait adalah gizi masyarakat. Penelitian ini merupakan penelitian eksperimen dengan metode pre and post test control groups design dengan membagi jumlah subjek menjadi dua kelompok yaitu, kelompok perlakuan dengan pemberian minuman jus mentimun dan kelompok kontrol yang tidak diberikan perlakuan. Pada pengambilan data awal, dilakukan penyaringan subjek terlebih dahulu dengan cara kuota sampling menggunakan kuesioner penyaringan serta dengan melakukan pengukuran tekanan darah selama 2 kali dalam waktu satu minggu sampai jumlah subjek minimal tercukupi yaitu 30 subjek. Metode ini dipilih sesuai dengan kriteria inklusi yaitu bersedia mengikuti penelitian dan dapat diajak berkomunikasi, mempunyai tekanan darah sistolik $\geq 140 \mathrm{mmHg}$ dan atau diastolik $\geq 90 \mathrm{mmHg}$, wanita berusia 40-60 tahun, tidak mengkonsumsi obat antihipertensi dalam satu minggu terakhir, tidak merokok, tidak mengkonsumsi alkohol dan tidak menderita penyakit Diabetes Mellitus, gagal ginjal, jantung, dan stroke. Sebesar 15 subjek yang bersedia mengkonsumsi jus mentimun dipilih sebagai kelompok perlakuan dan sisanya sebagai kelompok kontrol. Populasi terjangkau pada penelitian ini adalah ibu rumah tangga yang berumur 40-60 tahun yang tinggal di pemukiman Kelurahan Jomblang Semarang dan menderita hipertensi.

Variabel independen dalam penelitian ini adalah konsumsi jus mentimun yang mengandung 100 gram buah mentimun dan diukur dalam satuan mililiter (ml), variabel dependen tekanan darah sistolik dan diastolik yang diukur dengan Sphygmomanometer, dan variabel confounding adalah konsumsi natrium, kalium, kalsium, dan magnesium yang diukur dengan kuisioner food Recall selama 3 x 24 jam serta indeks masa tubuh (IMT). Konsumsi jus mentimun didefinisikan sebagai jumlah jus mentimun yang dikonsumsi oleh subjek sebanyak 1 gelas $(250 \mathrm{ml})$ yang mengandung 100 gram mentimun (Cucumis sativus l) dengan tingkat kematangan dan warna yang seragam, $80 \mathrm{ml}$ air matang dan $20 \mathrm{ml}$ sirup yang diberikan selama 7 hari berturut-turut sebanyak 2 kali pemberian dalam sehari. Data kepatuhan subjek dapat diamati setiap hari setelah pemberian jus mentimun.

Tekanan darah didefinisikan sebagai tekanan pada dinding pembuluh darah darah selama fase kontraksi dan fase relaksasi pada siklus jantung yang diukur dengan menggunakan Sphygmomanometer. Konsumsi natrium, kalium, 
kalsium, magnesium didefinisikan sebagai jumlah natrium, kalium, kalsium, magnesium yang dikonsumsi selama penelitian kemudian dihitung rata-rata per hari, diukur dengan menggunakan kuesioner food Recall selama 3 x 24 jam pada awal, pertengahan dan akhir penelitian. Data yang diperoleh dalam ukuran rumah tangga, kemudian dikonversikan dalam satuan gram.

Indeks massa tubuh (IMT) didefinisikan sebagai berat badan (dalam kilogram) dibagi dengan kwadrat tinggi badan (dalam ukuran meter). Data berat badan diperoleh dengan menggunakan timbangan digital glass scale dengan kapasitas $120 \mathrm{~kg}$ dan tingkat ketelitian $0,1 \mathrm{~kg}$ sedangkan data tinggi badan diperoleh dengan menggunakan microtoise dengan ukuran maksimal $200 \mathrm{~cm}$ dan tingkat ketelitian $0,1 \mathrm{~cm}$.

Pengolahan data dan analisis dilakukan dengan menggunakan program Statistical Package for Social Science (SPSS) 16.0 for Windows.
Analisis univariat untuk menguji kenormalan data menggunakan Shapiro-Wilk karena jumlah subyek $<50$. Analisis bivariat untuk mengetahui perbedaan tekanan darah sebelum dan sesudah intervensi menggunakan uji Paired $t$ test pada kelompok perlakuan, dan uji Wilcoxon pada kelompok kontrol karena data tidak berdistribusi normal.

\section{HASIL DAN PEMBAHASAN Karakteristik Subyek Penelitian}

Subjek dalam penelitian ini berjumlah 30 orang. Sebagian besar subjek berumur 50-60 tahun, IMT normal, memiliki riwayat hipertensi dalam keluarga dan tidak mempunyai kebiasaan olahraga. Tidak terdapat perbedaan umur, indeks massa tubuh, riwayat hipertensi dalam keluarga dan kebiasan olahraga antara kelompok perlakuan dan kontrol. Data selengkapnya dapat dilihat pada Tabel 1.

Tabel 1. Karakteristik subjek penelitian

\begin{tabular}{|c|c|c|c|c|c|c|}
\hline \multirow[t]{2}{*}{ Karakteristik Subjek } & \multicolumn{2}{|c|}{$\begin{array}{l}\text { Perlakuan } \\
(\mathrm{n}=15)\end{array}$} & \multicolumn{2}{|c|}{$\begin{array}{c}\text { Kontrol } \\
(\mathbf{n}=15)\end{array}$} & \multicolumn{2}{|c|}{ Total } \\
\hline & $\mathbf{n}$ & $\%$ & $\mathbf{N}$ & $\%$ & $\mathbf{n}$ & $\%$ \\
\hline \multicolumn{7}{|l|}{ Umur } \\
\hline $40-49$ Tahun & 5 & 33.3 & 0 & 0 & 5 & 16.7 \\
\hline $50-60$ Tahun & 10 & 66.7 & 15 & 100.0 & 25 & 83.3 \\
\hline \multicolumn{7}{|l|}{ Kategotri IMT } \\
\hline Normal & 9 & 60 & 10 & 66.7 & 19 & 63.3 \\
\hline Obesitas & 6 & 40 & 5 & 33.3 & 11 & 36.7 \\
\hline \multicolumn{7}{|l|}{ Riwayat hipertensi keluarga } \\
\hline Ada & 9 & 60.0 & 9 & 60.0 & 18 & 60.0 \\
\hline Tidak & 6 & 40.0 & 6 & 40.0 & 12 & 40.0 \\
\hline \multicolumn{7}{|l|}{ Kebiasaan olahraga } \\
\hline Olahraga & 5 & 33.3 & 4 & 26.7 & 9 & 30.0 \\
\hline Tidak olahraga & 10 & 66.7 & 11 & 73.3 & 21 & 70,0 \\
\hline
\end{tabular}

Berdasarkan tabel 1, diketahui subjek dalam penelitian ini sebagian besar $(83,3 \%)$ berumur 50-60 tahun. Beberapa penelitian menunjukkan bahwa prevalensi hipertensi meningkat secara signifikan dengan bertambahnya umur pada semua jenis kelamin dan kelompok ras. Prevalensi tersebut meningkat dari $22 \%$ pada kelompok usia 40-49 tahun, menjadi 37,5\% pada kelompok usia 50-59 tahun. Hal ini disebabkan elastisitas dinding pembuluh darah semakin menurun dengan bertambahnya umur. ${ }^{10,14}$

Obesitas juga berpengaruh terhadap peningkatan tekanan darah, terutama obesitas sentral. Beberapa penelitian epidemiologi membuktikan bahwa mayoritas penderita hipertensi adalah orang-orang yang mengalami obesitas. Setiap kelebihan berat badan sebesar $10 \mathrm{~kg}$, tekanan darah sistolik meningkat sekitar $3 \mathrm{mmHg}{ }^{15}$
Beberapa perubahan fisiologi menjelaskan kaitan antara kelebihan berat badan dan tekanan darah yaitu resistensi insulin dan hiperinsulinemia, aktifnya saraf simpatis dan sistem renin angiotensin serta perubahan fisiologi ginjal. Meningkatnya asupan energi akan meningkatkan insulin plasma, yang mana penyerapan natrium di ginjal akan bertambah sehingga banyak cairan yang tertahan dan menyebabkan peningkatan tekanan darah. Prevalensi hipertensi pada orang-orang yang memiliki IMT $>30 \mathrm{~kg} / \mathrm{m}^{2}$ adalah $38 \%$ untuk lakilaki dan $32 \%$ untuk perempuan. Bila dibandingkan dengan orang-orang yang memiliki IMT $<25 \mathrm{~kg} / \mathrm{m}^{2}$ prevalensi hipertensi lebih rendah yaitu $18 \%$ untuk laki-laki dan $17 \%$ untuk perempuan. ${ }^{16}$

Riwayat hipertensi dalam penelitian ini adalah sebesar $60 \%$. Berbagai faktor seperti faktor genetik yang menimbulkan perubahan pada ginjal 
dan membran sel, aktivitas saraf simpatis, dan sistem renin-angiotensin yang mempengaruhi keadaan hemodinamik, asupan natrium dan metabolisme natrium dalam ginjal mempunyai peran dalam peningkatan tekanan darah pada hipertensi primer. ${ }^{1}$

Persentase subjek pada penelitian ini yang melakukan olahraga rutin hanya sebesar $30 \%$. Jenis olah raga yang dilakukan subjek adalah berjalan kaki. Orang-orang yang kurang beraktivitas memiliki risiko $30-50 \%$ lebih tinggi mengalami hipertensi dibanding mereka yang aktif. Dua studi metaanalisa menunjukkan adanya pengaruh aktivitas fisik terhadap tekanan darah dimana pada analisa pertama menunjukkan bahwa berjalan kaki dapat menurunkan tekanan darah orang dewasa rata-rata sebesar $2 \%$. Analisa kedua menunjukkan bahwa olahraga aerobik dapat menurunkan tekanan darah dengan rata-rata 4 $\mathrm{mmHg}$ dan $2 \mathrm{mmHg}$ pada pasien yang mengalami hipertensi ataupun tidak. Sehingga, peningkatan aktifitas fisik dengan intensitas ringan hingga sedang selama 30-45 menit secara rutin sangat penting sebagai strategi pencegahan terjadinya hipertensi primer. ${ }^{16}$

\section{Perbedaan tekanan darah}

Berdasarkan hasil penelitian diketahui bahwa terdapat perbedaan rerata tekanan darah sistolik dan diastolik antara sebelum dan setelah intervensi pada kelompok perlakuan. Sedangkan pada kelompok kontrol terdapat peningkatan rerata tekanan darah sistolik dan tekanan darah diastolik. Data selengkapnya dapat dilihat pada Tabel 2

Tabel 2. Tekanan darah sebelum dan setelah intervensi

\begin{tabular}{lcccccc}
\multicolumn{7}{c}{ Tabel 2. Tekanan darah sebelum dan setelah intervensi } \\
\hline & \multicolumn{2}{c}{ Perlakuan $(\mathrm{n}=15)$} & & \multicolumn{2}{c}{ Kontrol $(\mathrm{n}=15)$} & \multirow{2}{*}{ Nilai $\mathrm{p}$} \\
\cline { 2 - 3 } \cline { 5 - 6 } & Rerata & SD & & Rerata & SD & \\
\hline Sistolik awal $(\mathrm{mmHg})$ & 161.00 & 17.55 & 0.000 & 157.33 & 15.796 & 0.022 \\
Sistolik akhir $(\mathrm{mmHg})$ & 145.00 & 16.58 & & 164.33 & 17.614 & \\
& & & & & & \\
\hline Diastolik awal(mmHg) & 92.67 & 10.99 & 0.002 & 91.67 & 5.876 & 0.014 \\
$\begin{array}{l}\text { Diastolik akhir } \\
(\mathrm{mmHg})\end{array}$ & 86.00 & 12.98 & & 95.67 & 5.627 & \\
\hline
\end{tabular}

Terdapat perbedaan rerata penurunan tekanan darah sistolik dan diastolik antara kelompok perlakuan dan kelompok kontrol, dimana penurunan tekanan darah sistolik dan diastolik pada kelompok perlakuan sebesar $16 \pm 8.062 \mathrm{mmHg}$ dan
$6.67 \pm 6.726$ mmHg. Sedangkan pada kelompok kontrol justru terjadi peningkatan rerata tekanan darah baik pada tekanan darah sistolik maupun diastolic yaitu sebesar 5 dan $2.67 \mathrm{mmHg}$. Data selengkapnya dapat dilihat pada Tabel. 3

Tabel 3. Penurunan tekanan darah

\begin{tabular}{rcccc}
\hline \multirow{2}{*}{ Karakteristik Subyek } & \multicolumn{2}{c}{ Perlakuan $(\mathrm{n}=15)$} & \multicolumn{2}{c}{ Kontrol $(\mathrm{n}=15)$} \\
\cline { 2 - 5 } & Mean & SD & Mean & SD \\
\hline Penurunan sistolik & 16 & 8.062 & -5 & 11.019 \\
Penurunan diastolik & 6.67 & 6.726 & -2.67 & 5.936
\end{tabular}

Besarnya rerata penurunan tekanan darah pada penelitian ini lebih tinggi dibandingkan penelitian sebelumnya karena penelitian ini dilakukan dengan waktu yang lebih lama dan dengan frekuensi pemberian sebanyak 2 kali dalam sehari.

Mentimun memiliki berbagai macam kandungan gizi diantaranya adalah kalium, kalsium, dan magnesium ${ }^{17}$ Berbagai penelitian membuktikan bahwa ada kaitan erat antara intake kalium, kalsium, dan magnesium terhadap penurunan tekanan darah. ${ }^{16,18,19}$ Semakin rendah intake kalium maka tekanan darah akan semakin tinggi. Rasio natrium/kalium juga berhubungan dengan tekanan darah. Dengan pengurangan intake natrium sebesar $100 \mathrm{mmol}$ perhari dan konsumsi kalium sampai dengan 70 mmol dalam sehari, maka tekanan darah sistolik diprediksi akan turun sebesar 3,4 mmHg. Intake kalium berpengaruh pada pembuluh darah yaitu kalium akan menurunkan resistensi pembuluh darah perifer yang secara langsung dapat melebarkan arteri, peningkatan pengeluaran air dan natrium dari tubuh, penekanan sekresi renin angiotensin, dan stimulasi dari aktivitas pompa natrium-kalium. ${ }^{16}$ Kalium mempunyai efek natriuretik dengan cara menghambat pelepasan renin-angiotensin yang dapat meningkatkan ekskresi natrium dan air. Hal 
tersebut, menyebabkan terjadinya penurunan volume plasma, curah jantung, dan tekanan perifer sehingga tekanan darah akan turun. ${ }^{19}$

Beberapa penilitian menunjukkan adanya hubungan antara asupan kalsium dengan tekanan darah, dimana asupan kalsium yang rendah dapat meningkatkan prevalensi hipertensi. Pada studi epidemiologi, diketahui bahwa kelompok dengan tingkat konsumsi kalsium yang rendah (300$600 \mathrm{mg} / \mathrm{hari}$ ) cenderung meningkatkan tekanan darah. Kadar kalsium yang rendah dalam darah akan merangsang paratiroid hormon dan mengakibatkan kadar ion kalsium intrasel meningkat. Hal tersebut menyebabkan sel otot polos pembuluh darah hiperaktif terhadap zat-zat penekan sehingga resistensi perifer pembuluh darah dapat meningkat yang juga akan meningkatkan tekanan darah. ${ }^{19}$

Studi menunjukkan bahwa asupan kalsium yang cukup (700-800 $\mathrm{mg} / \mathrm{hr}$ ) berpengaruh terhadap penurunan tekanan darah meskipun pengaruhnya belum terlihat. Penelitian yang dilakukan pada hewan hipertensi dengan suplementasi kalsium, menunjukkan penurunan darah yang signifikan. Meskipun studi pada manusia tidak menunjukkan perubahan, tetapi penurunan tekanan darah akibat suplementasi kalsium terlihat pada subyek dengan asupan natrium yang tinggi. ${ }^{5,19,20}$

Magnesium merupakan vasodilator yang berperan dalam pengaturan tekanan darah dengan menurunkan kontraktilitas pembuluh darah. Selain itu magnesium dalam sel endotel manusia dapat menstimulasi produksi prostaglandin $\mathrm{I}_{2}$. Ketika magnesium serum meningkat secara akut maka dapat berfungsi sebagai vasodilator. Sebaliknya, bila kekurangan magnesium berhubungan dengan resistensi insulin yang menstimulasi penangkapan glukosa dan meningkatkan kontraktilitas vaskular. Berbagai studi klinik menunjukkan, terjadi penurunan tekanan darah secara signifikan pada pasien eklamsia dan glomerulonefritis yang diberikan magnesium dosis tinggi dengan cara parenteral. ${ }^{19}$

Asupan Natrium, Kalium, Kalsium dan Magnesium

Asupan natrium, kalium, kalsium dan magnesium selama intervensi diperoleh dari rata-rata asupan makan dan minum selama tiga hari. Rerata asupan natrium pada kelompok perlakuan $2911.97 \mathrm{mg}$ sedangkan pada kelompok kontrol yaitu 2894.04 mg. Rerata asupan natrium pada kedua kelompok tergolong tinggi. Rerata asupan kalium, kalsium dan magnesium kelompok perlakuan dan kontrol selama intervensi tergolong kurang jika dibandingkan dengan jumlah kebutuhan sehari. ${ }^{21}$ Hal tersebut sesuai dengan teori yang mengatakan bahwa salah satu faktor yang mempengaruhi kejadian hipertensi adalah asupan makanan, yaitu asupan tinggi natrium, dan rendah kalium, kalsium, serta magnesium. ${ }^{5,16,22}$

Tabel 4. Asupan natrium, kalium, kalsium dan magnesium selama intervensi

\begin{tabular}{lcccc}
\hline & \multicolumn{2}{c}{ Perlakuan $(\mathrm{n}=15)$} & \multicolumn{2}{c}{ Kontrol (n=15) } \\
\cline { 2 - 5 } & Mean & SD & Mean & SD \\
\hline Asupan natrium (mg) & 2911.97 & 346.87 & 2894.04 & 258.74 \\
Asupan kalium (mg) & 1260.07 & 204.87 & 1361.84 & 270.02 \\
Asupan kalsium (mg) & 328.49 & 166.31 & 343.39 & 118.37 \\
Asupan magnesium (mg) & 280.71 & 90.83 & 276.96 & 69.67 \\
\hline
\end{tabular}

\section{SIMPULAN}

Pemberian jus mentimun dengan dosis 100 gram buah mentimun pada penderita hipertensi selama 7 hari dengan frekuensi 2 kali pemberian dalam sehari terbukti menurunkan tekanan darah.

\section{SARAN}

Perlu diadakan penelitian lebih lanjut dengan waktu intervensi yang lebih lama serta pengambilan subjek dilakukan secara random.

\section{DAFTAR PUSTAKA}

1. Arjatmo Tjokronegoro, Hendra U. Buku Ajar Penyakit Dalam. Jakarta :Balai Penerbit FKUI, 2001.hal.453.
2. Arif Mansjoer, dkk. Kapita Selekta Kedokteran jilidI. Jakarta: Media Aesculapius, 2001.hal.518-9.

3. Badan Penelitian dan Pengembangan Kesehatan Kementerian Kesehatan RI. Laporan Hasil Riset Kesehatan Dasar (RISKESDAS) Nasional 2013. Jakarta; 2013.hal.123.

4. Dinas Kesehatan Kota Semarang. Profil Kesehatan Kota Semarang 2012. Semarang: Dinas Kesehatan Kota Semarang; 2012.hal.70.

5. Charlton KE. Diet and Blood pressure. In Temple NJ, Wilson T, Jacobs DR. Nutrition Health ForDesease Prevention. 2nd ed. Human Press; 2006. p.111-27.

6. Blackburn GL. Functional Food in the Prevention and Treatment of Desease: Significance of the Dietary Approaches to Stop Hypertension Study. Am J Clin Nutr [serial online] 1997 [dikutip pada 
Februari 2014];66;1067-71. Available from: URL: HYPERLINK http://www.ajcn.org

7. Elis M, Muflihah I. Pengaruh Pemberian Jus Pepaya, Jus Semangka, dan Jus Melon Terhadap Penurunan Tekanan Darah Sistolik dan Diastolik. [KTI]: Ilmugizi; Unv. Diponegoro;2007.

8. Sulistiyono $\mathrm{H}, \mathrm{M}$ Isnawati. Pengaruh Pemberian Jus Belimbing Demak (AverrhoeCarambola L) Terhadap Penurunan Tekanan Darah Sistolik dan Diastolik pada Penderita Hipertensi. [KTI]: IlmuGizi; Unv. Diponegoro;2009.

9. Zauhani K, Zainal M. Efek Pemberian Jus Mentimun Terhadap Penurunan Tekanan Darah; Available from : Academia.edu.2014.hal.246.

10. DendyK,Wan ND, Widia L. Efektifitas Konsumsi Jus Mentimun Terhadap Penurunan Tekanan Darah Pada Penderita Hipertensi. Jurnal Ners Indonesia. 2012; vol.2:2:124-31.

11. Iswidhani, Suhaema, Fifi L, M Alfin. Perbedaan Tekanan Darah Pasien Hipertensi Sebelum dan Sesudah Pemberian Jus Mentimun (CucumisSativus L) Puskesmas Denggen Kecamatan Selong Kabupaten Lombok Timur. Media Bina Ilmiah. 2014; Vol 8:1:63-67. ISSN No. 1978-3787.

12. Fauziah Rahmah Karim. Pemanfaatan Mentimun terhadap Penurunan Tekanan Darah pada Penderita Hipertensi di Dusun Desa Pulau Sejuk Kecamatan Lima Puluh Kabupaten Batu Bara. [KTI]: Fakultas Keperawatan; Unv. Sumatera Utara;2010.

13. Dreisbach AW. Hypertension. [serial online] 2010 [dikutip pada 18Maret2012];Available from: URL: HYPERLINK

http://www.emedicine.medscape.com

14. Bakris GL. Hipertensi. Dalam: Stein JH. Panduan Klinik Ilmu Penyakit Dalam: alih bahasa Nugroho E; editor edisi bahasa Indonesia: Komala S, Santoso AH. edisi ke-3. Jakarta: EGC.1998.hal.218-38.

15. Kretchmer N, Zimmerman M. Developmental Nutrition. Allyn\& Bacon; 1997.p.546-54.

16. Debra AK. Medical Nutrition in Hypertension. In: Mahan K,Escott-Stump S editors. Krause's food, nutrition and diet therapy. 11th ed. Philadelphia: Saunders; 2004.p.900-18.

17. Hapsoh, Rahmawati N. Terapi Jus Dari Sayuran Buah dan Sayuran Daun Mentimun (CucumisSativus L) [serial online] 2012 [dikutip pada 17 Juni2012]; Available from: URL: HYPERLINKhttp://ocw.usu.ac.id.

18. D Jamy. Hypertension. In: Heimburger DC, D Jamy. Handbook of Clinical Nutrition.4th ed. Mosby Elsevier;2004.p.413-19.

19. Kotchen AK, Kotchen JM. Nutrition, Diet And Hypertension. In Shils ME, Shike M, Ross AC, Cabelloro, Cousins RJ. Modern Nutrition In Health Desease.10th ed. Philadelphia: Lippincott Williams \& Wilkins; 2006.p.1095-105.
20. Insel P, Turner RE, Ross D. Discovering Nutrition. 2nd ed. American Dietetic Association; 2006.p.406-16.

21. Menteri Kesehatan Republik Indonesia. Peraturan Menteri Kesehatan Republik Indonesia No 75 Tahun 2013;Angka Kecukupan Gizi Yang Dianjurkan Bagi Bangsa Indonesia; 2013.

22. Gray HH, Dawkins KD, Morgan JM. Hipertensi. Dalam: Safitri A. Lecture Notes Kardiologi. edisi ke-4. Jakarta: Erlangga; 2005.hal.57-69. 